\title{
PENGARUH ATRIBUT PRODUK DALAM MENDORONG NIAT BELI SMARTPHONE OPPO DI KOTA PALU
}

\author{
Ade Reny Paputungan \\ Syamsul Bachri \\ Ponirin \\ Program Studi S1 Manajemen, Fakultas Ekonomi, Universitas Tadulako \\ Email: paputungan_adereny@yahoo.com; syamsulbachri09@gmail.com; ppaidjan@gmail.com
}

\begin{abstract}
This study aims to find out and analyze: (1) product attribute variables consisting of quality, features, designs, and brands simultaneously have a significant effect on the purchase intention of Oppo brand smartphone products in Palu city (2) product attribute variables partially have a significant effect on intention to buy Oppo smartphone products in the city of Palu. The type of research used is causality. The population of this study is all the people of Palu city who do not have or buy an Oppo smartphone. Sampling techniques in this study used purposive sampling, with a sample of 50 respondents. The analysis method uses multiple linear regression analysis. The results of the study show that (1) product attribute variables simultaneously have a significant effect on the purchase intention of the Oppo brand smartphone in the city of Palu (2) product attribute variables partially have a significant effect on the intention to buy Oppo brand smartphone in Palu city.
\end{abstract}

Keywords: Product Attributes, Purchase Intention.

\begin{abstract}
Abstrak
Penelitian ini bertujuan untuk mengetahui dan menganalisa: (1) variabel atribut produk yang terdiri atas kualitas, fitur, desain, dan merek secara serempak berpengaruh signifikan terhadap niat beli produk smartphone merek Oppo di Kota Palu (2) variabel atribut produk secara persial berpengaruh signifikan terhadap niat beli produk smartphone Oppo di kota Palu. Jenis penelitian yang digunakan adalah kausalitas. Populasi penelitian ini adalah seluruh masyarakat Kota Palu yang belum memiliki atau membeli smartphone Oppo. Teknik penarikan sampel dalam penelitian ini menggunakan purposive sampling, dengan jumlah sampel 50 responden. Metode analisis menggunakan analisis regresi linear berganda. Hasil penelitian menunjukkan bahwa (1)Variabel atribut produk yang terdiri dari kualitas produk, fitur, desain, dan merek secara serempak berpengaruh signifikan terhadap niat beli smartphone merek Oppo di Kota Palu (2) Variabel atribut produk secara parsial berpengaruh signifikan terhadap niat beli smartphone merek Oppo di Kota Palu.
\end{abstract}

Kata Kunci: Atribut Produk, Niat Beli.

\section{PENDAHULUAN}

Teknologi informasi dan komunikasi saat ini berkembang pesat membuat masyarakat terdorong untuk memiliki alat yang mampu memenuhi kebutuhan mereka untuk mengakses informasi, salah satunya adalah smartphone. Sejalan dengan perkembangan teknologi, fungsi komunikasi yang awalnya sederhana seperti yang dulu dimiliki oleh handphone kini berkembang menjadi smartphone guna mengakomodasi kebutuhan manusia yang semakin meningkat terutama dalam mengakses teknologi informasi dan komunikasi.

Upaya yang harus dilakukan perusahaan dalam memenuhi keinginan dan kebutuhan konsumen serta mempertahankan kelangsungan hidup perusahaan adalah dengan melakukan strategi pemasaran yang tepat dan terarah, seperti meningkatkan atribut produk, kebijakan harga dan memilih media promosi yang tepat untuk dapat menghadapi persaingan yang semakin ketat.

Perusahaan harus mampu membaca apa yang diinginkan oleh konsumen sebelum mereka memproduksi produk mereka agar produk yang telah diproduksi tersebut diminati oleh banyak konsumen dan mereka memutuskan untuk membeli produk dari perusahaan tersebut. Menurut Kotler (2008) niat beli merupakan suatu hal yang mendahului dan menentukan suatu pelanggan. 
Smartphone sekarang ini bukan hanya sebagai penunjang kebutuhan berkomunikasi saja, banyak fungsi lain yang lebih menarik yang didapat dari perangkat smartphone. Beberapa fungsi tersebut antara lain untuk permainan, jelajah internet, keperluan bisnis, dan masih banyak fungsi lainnya dengan banyaknya dukungan dari pengembang aplikasi smartphone.

Setelah lahirnya sistem operasi Android yang bekerja pada smartphone, banyak perusahaanperusahaan yang memproduksi smartphone mengadopsi sistem operasi tersebut. Beberapa diantaranya yang menggunakan sistem Android tersebut adalah Samsung, Sony, LG, Motorola, bahkan hingga perusahaan-perusahaan China seperti Vivo, Oppo, Lenovo, dan Huawei turut berlomba memproduksi perangkat smartphone dengan menggunakan Android sebagai sistem operasinya. OPPO Electronic Corp, Ltd. merupakan salah satu pendatang baru yang ikut andil dalam meramaikan pasar Smartphone.

Berikut atribut Oppo yang membedakan dengan merek lain antara lain kualitas produk yaitu salah satu alat utama pemasar. Kualitas memiliki dampak langsung terhadap kinerja produk atau layanan, sehingga terkait erat dengan nilai dan kepuasan pelanggan (Kotler dan Amstrong, 2013:254). Perlu untuk diketahui ketika membeli smartphone Oppo, kualitasnya yang premium membuat atribut produk dari perusahaan ini dijuluki sebagai Apple-nya dunia android. Oppo identik dengan dua hal yaitu yang pertama adalah baterai yang kuat dan tahan lama. Baterai dari Oppo cenderung tahan lebih lama dibandingkan dengan produk smartphone lainnya dan tidak mudah rusak dalam jangka waktu yang panjang. Dan Oppo dilengkapi dengan teknologi VOOC Fast Charging, di mana hanya dalam kurun waktu 30 menit bisa mengisi daya baterai lebih dari 75\%. Dengan VOOC Fast Charging ini, tidak akan membuat smartphone mudah rusak.

Hal kedua fitur poduk adalah sarana kompetitif untuk membedakan produk peusahaan dengan produk pesaing (Kotler dan Amstrong, 2013:254) yaitu kameranya yang super, julukan untuk kamera Oppo ini yaitu "cameraphone". Oppo benar-benar membuktikan bahwa menggabungkan kualitas kamera dengan smartphone premium membuahkan hasil yang sempurna, sehingga slogan mereka untuk F1s berbunyi "The New Selfie Expert" dengan resolusi kamera depan 16 MP yang didukung oleh aplikasi "percantik" wajah, dan kamera belakang dengan resolusi kamera 13 MP jauh lebih tajam dari resolusi kamera smartphone 13 MP pada umumnya. Bahkan lebih tajam dari resolusi kamera 13 MP-nya F1s Limited Black Edition dalam segi tampilan warna.

Lini produk Oppo meliputi ponsel, pemutar MP3, televisi LCD, pemutar DVD/blu-ray, dan pembaca buku elektronik. Oppo mempunyai divisi bernama Oppo DigitalInc, merek meupakan suatu istilah, tanda, simbol, atau rancangan yang dimasukkan untuk mengidentifikasi barang/jasa untuk menjadi bahan pembeda dari barang/jasa pesaing (Kotler dan Armstrong, 2013:255). Oppo DigitalInc dikenal lewat produk pemutar DVD dan blu-ray. Perusahaan itu berada di Mountain View, California, AS.

Oppo baru terjun ke bisnis ponsel pada 2008. Namun, prestasinya tak bisa dipandang sebelah mata. Oppo Finder, ponsel setebal 6,65 mm yang diperkenalkan pada pertengahan tahun 2012, saat itu tampil sebagai smartphone paling tipis di dunia, selain itu, Oppo juga menggunakan brand ambassador yang terkenal dikalangan anak muda seperti Dian Sastrowardoyo, Chelsea Islan, Nicholas Saputra, Reza Rahardian, dan lain-lain.

Market share smartphone Oppo di Indonesia tahun 2017 mengalami peningkatan sebesar 8,8\% dari tahun sebelumnya, dan masih tetap menduduki posisi kedua, di mana posisi pertama di duduki oleh smartphone Samsung yang berasal dari negeri ginseng (Korea Selatan).

Peningkatan penjualan dan tanggapan positif dari keluarga dan teman-teman yang merekomendasikan ataupun menjelaskan tentang kualitas dan keunggulan fitur yang ada pada smartphone Oppo membuat peneliti tertarik melakukan penelitian terhadap smartphone Oppo guna untuk mengetahui pengaruh atribut produk Oppo terhadap niat beli. 
penjualan smartphone Oppo di Kota Palu setiap tahunnya mengalami peningkatan dibandingkan dengan tahun sebelumnya. Hal ini dikarenakan smartphone Oppo memiliki kualitas produk, yang terpercaya, memiliki fitur kamera super yang sesuai dengan kebutuhan masyarakat, tidak hanya dikalangan remaja tetapi juga semua kalangan, baik tua maupun muda yang sekedar ingin membagikan momen bersama keluarga dan keindahan Kota Palu melalui fitur kamera super yang dimiliki Oppo. Selain itu desain Oppo yang sangat elegan membuat seseorang berminat dan berniat untuk memiliki salah satu produk smartphone Oppo ini.

Menurut Kotler (2008) cara lain untuk menambah nilai pelanggan adalah melalui desain atau rancangan produk yang berbeda dari yang lain. Desain merupakan rancangan bentuk dari suatu produk yang dilakukan atas pandangan bahwa "bentuk ditentukan oleh fungsi" di mana desain mempunyai kontribusi terhadap manfaat dan sekaligus menjadi daya tarik produk karena produk mempertimbangkan faktor-faktor estetika, ergonomis, dan bahan-bahan lainnya.

Sebelum konsumen melakukan pembelian atau berniat melakukan pembelian perlu adanya evaluasi terhadap kebutuhan dengan produk yang dibutuhkan atau diinginkan. Dengan adanya merek dapat mempermudah konsumen untuk mencari tahu apakah produk tersebut menawarkan atribut produk yang sesuai dengan kebutuhan konsumen atau tidak. Setelah itu munculah niat beli yang dapat menimbulkan keputusan pembelian.

\section{KAJIAN LITERATURE DAN PENGEMBANGAN HIPOTESIS}

Menurut Kotler dan Amstrong (2013:29), pemasaran adalah proses dimana perusahaan menciptakan nilai bagi pelanggan dan membangun hubungan pelanggan yang kuat untuk mendapatkan nilai dari pelanggan sebagai imbalannya.Menurut American Marketing Association (AMA) (Malau, 2017), mendefinisikan bahwa pemasaran adalah suatu aktivitas dan proses menciptakan, mengkomunikasikan, memberikan, dan menawarkan pertukaran nilai terhadap pelanggan, klien, rekan, dan masyarakat luas.

Menurut Kotler dan Armstrong (2013:248) yaitu produk sebagai segala sesuatu yang ditawarkan kepada pasar agar menarik perhatian, akuisisi, penggunaan, atau konsumsi yang dapat memuaskan suatu keinginan dan kebutuhan. Malau (2017) mendefinisikan produk sebagai barang nyata atau tidak nyata yang dapat dijual kepada orang lain. Aspek produk yang diciptakan itu dapat di spesifikasi dengan benda atau jasa. Menurut Abdullah dan Tantri (2014:153) produk didefinisikan sebagai segala sesuatu yang dapat ditawarkan ke pasar untuk mendapatkan perhatian, dibeli, dipergunakan, atau dikonsumsi dan yang dapat memuaskan keinginan atau kebutuhan.

Atribut produk mempunyai pengaruh besar terhadap persepsi pembeli terhadap produk. Tjiptono (2008:103) mengungkapkan bahwa atribut produk adalah unsur-unsur produk yang dipandang penting oleh konsumen dan dijadikan dasar pengambilan keputusan pembelian. Atribut produk meliputi merek, kemasan, jaminan atau mutu, pelayanan dan sebagainya.Menurut Kotler dan Amstrong (2013:254) kualitas produk adalah salah satu alat utama pemasar, fitur adalah alat yang kompetitif untuk membedakan produk perusahaan dari produk pesaing. Desain memiliki konsep yang lebih luas dari pada gaya (style) (Kotler dan Armstrong, 2013:254). Desain selain mempertimbangkan faktor penampilan, juga bertujuan untuk memperbaiki kinerja produk, mengurangi biaya produksi, dan menambah keunggulan bersaing. Menurut Kotler dan Armstrong (2013:255) merek merupakan suatu istilah, tanda, simbol, atau rancangan, atau kombinasi dari semuanya, yang dimaksudkan untuk mengidentifikasi barang atau jasa penjual atau kelompok penjual dan untuk menjadi bahan pembeda dari barang atau jasa pesaing.

Minat beli berbeda dengan niat beli, niat beli adalah suatu tindakan yang mengarah pada keputusan pembelian atau sudah dalam persentase yang besar untuk melakukan pembelian. Jadi dapat dikatakan bahwa niat beli merupakan keyakinan sebelum keputusan pembelian diambil. Selain itu, niat beli 
terhadap suatu produk juga dapat terjadi dengan adanya pengaruh dari orang lain yang dipercaya oleh calon konsumen.

\section{METODE PENELITIAN}

Jenis penelitian ini adalah kausal dan data yang diperoleh dianalisis secara kuantitatif. Metode penelitian kuantitatif dapat diartikan sebagai metode penelitian yang berlandaskan pada filsafat positivisme, digunakan untuk meneliti pada populasi atau sampel tertentu, teknik pengambilan sampel pada umumnya dilakukan secara random, pengumpulan data menggunakan instrument penelitian, analisis data bersifat kuantitatif/statistik dengan tujuan menguji hipotesis yang telah ditetapkan (Sugiyono, 2015:11).

Lokasi untuk penelitian ini dilakukan di outlet Oppo Elektronik Indonesia Jl. H. Hayyun No. 50c di Kota Palu. Jenis data kuantitatif yang digunakan yaitu data responden, uji instrumen penelitian, uji asumsi klasik dan metode analisis untuk membuktikan hubungan dan pengaruh antar variabel bebas dan terikat. Menggunakan skala nominal, dan ordinal. Data kualitatif yang digunakan adalah dokumentasi dan sejarah. Data primer yang diambil pada penelitian ini adalah data karakteristik responden (jenis kelamin, usia, pekerjaan, gaji, merek hp/smartphone yang digunakan, dan frekuensi berkunjung di outlet Oppo) dan jawaban responden. Sumber data sekunder dalam penelitian ini yaitu sejarah singkat, visi dan misi Oppo Elektronik Indonesia Palu, data penjualan yang telah disediakan oleh Oppo Elektronik Indonesia Palu, market share smatphone, dan jurnal. Populasi dalam penelitian ini adalah seluruh masyarakat Kota Palu yang belum memiliki atau membeli smartphone Oppo, akan tetapi sudah mengetahui smartphone merek Oppo melalui iklan, evaluasi atau mencari informasi tentang smartphone Oppo, batas minimum usia 15 tahun. Karena tidak adanya data yang menunjukkan jumlah populasi tentang hal tersebut, maka populasi dalam penelitian ini jumlahnya tidak diketahui atau non probability sampling. Teknik penarikan sampel yang digunakan adalah teknik purposive sampling di mana peneliti memilih sampel berdasarkan penilaian terhadap beberapa karakteristik anggota sampel yang disesuaikan dengan maksud peneliti (Kuncoro, 2009:139). Untuk menentukan jumlah atau besaran sampel, maka peneliti merujuk pada Sugiyono (2014) yang mengatakan bahwa untuk penelitian multivariat (regresi dan korelasi) maka jumlah sampel yang ideal adalah minimal 10 kali variabel (independen dan dependen). Berdasarkan teori tersebut maka jumlah sampel dalam penelitian ini ditetapkan dengan ketentuan $10 \mathrm{X}(4+1)$ yaitu 50 responden.

\section{HASIL DAN PEMBAHASAN}

\section{Uji Analisis Regresi Linear Berganda}

Tabel 4. Hasil Uji Analisis Regresi Linear Berganda

\begin{tabular}{|c|c|c|c|c|c|c|}
\hline & \multirow[b]{2}{*}{ Model } & \multicolumn{2}{|c|}{$\begin{array}{l}\text { Unstandardized } \\
\text { Coefficients }\end{array}$} & \multirow{2}{*}{$\begin{array}{c}\text { Standardized } \\
\text { Coefficients } \\
\text { Beta } \\
\end{array}$} & \multirow[b]{2}{*}{$\mathrm{T}$} & \multirow[b]{2}{*}{ Sig. } \\
\hline & & B & Std. Error & & & \\
\hline \multirow[t]{5}{*}{1} & (Constant) & .399 & .218 & & 1.832 & .074 \\
\hline & Kualitas produk & .640 & .048 & .769 & 13.420 & .000 \\
\hline & Fitur produk & .214 & .057 & .221 & 3.761 & .000 \\
\hline & Desain produk & .219 & .057 & .242 & 3.830 & .000 \\
\hline & Merek produk & .148 & .039 & .200 & 3.843 & .000 \\
\hline \multicolumn{2}{|c|}{$\begin{aligned} \mathrm{R} & =0.958^{\mathrm{a}} \\
\mathrm{R}^{2} & =0.917\end{aligned}$} & \multicolumn{3}{|c|}{$\begin{array}{c}\text { Sig.F }=0.000^{\mathrm{a}} \\
F=124.980\end{array}$} & & \\
\hline
\end{tabular}

Sumber: Data Diolah 


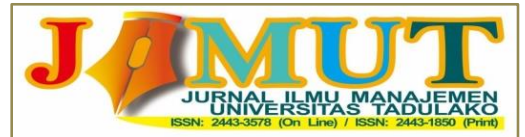

Vol. 7, No 1, Januari 2021, 021-029

Berdasarkan nilai dari Tabel 4, maka persamaan regresi linear berganda dapat dirumuskan sebagai berikut:

$$
\mathrm{Y}=0,399+0,640 \mathrm{X}_{1}+0,214 \mathrm{X}_{2}+0,219 \mathrm{X}_{3}+0,148 \mathrm{X}_{4}
$$

Persamaan tersebut dapat dinyatakan bahwa variabel independen $\left(\mathrm{X}_{1}, \mathrm{X}_{2}, \mathrm{X}_{3}, \mathrm{X}_{4}\right)$ memberi pengaruh positif terhadap variabel dependen (Y).

1. Nilai konstanta sebesar 0,399 berarti niat beli pada smartphone Oppo di Kota Palu sebelum adanya variabel independen adalah sebesar 0,399.

2. Kualitas produk $\left(X_{1}\right)$ dengan nilai koefisien regresi 0,640 , hal ini berarti terjadi pengaruh positif antara kualitas produk terhadap niat beli. Hal ini menyatakan bahwa jika kualitas produk ditingkatkan maka akan meningkat pula niat beli konsumen pada produk smartphone merek Oppo di Kota Palu.

3. Fitur produk $\left(\mathrm{X}_{2}\right)$ dengan nilai koefisien regresi 0,214 , hal ini berarti terjadi pengaruh positif antara fitur produk terhadap niat beli. Hal ini menyatakan bahwa jika fitur produk ditingkatkan maka akan meningkat pula niat beli konsumen pada produk smartphone merek Oppo di Kota Palu.

4. Desain produk $\left(\mathrm{X}_{3}\right)$ dengan nilai koefisien regresi 0,219 , hal ini berarti terjadi pengaruh positif antara desain produk terhadap niat beli. Hal ini menyatakan bahwa jika desain produk ditingkatkan maka akan meningkat pula niat beli konsumen pada produk smartphone merek Oppo di Kota Palu.

5. Merek produk $\left(\mathrm{X}_{4}\right)$ dengan nilai koefisien regresi 0,148 , hal ini berarti terjadi pengaruh positif antara merek produk terhadap niat beli. Hal ini menyatakan bahwa jika merek produk ditingkatkan maka akan meningkat pula niat beli konsumen pada produk smartphone merek Oppo di Kota Palu.

Untuk mengetahui pengaruh signifikan secara simultan maupun secara parsial dari variabel independen yakni kualitas produk $\left(\mathrm{X}_{1}\right)$, fitur produk $\left(\mathrm{X}_{2}\right)$, desain produk $\left(\mathrm{X}_{3}\right)$ dan merek produk $\left(\mathrm{X}_{4}\right)$ terhadap variabel dependen yakni niat beli $(\mathrm{Y})$, maka digunaka uji $\mathrm{F}$ dan uji t. Penjelasan lebih lengkapnya akan dijelaskan dibawah:

a. Berdasarkan Tabel 4 terlihat hasil perhitungan diperoleh nilai signifikansi $F=0,000<0,05$. Kesimpulannya adalah bahwa variabel independen yakni kualitas produk $\left(\mathrm{X}_{1}\right)$, fitur produk $\left(\mathrm{X}_{2}\right)$, desain produk $\left(\mathrm{X}_{3}\right)$, dan merek produk $\left(\mathrm{X}_{4}\right)$ secara serempak berpengaruh signifikan terhadap variabel dependen yakni niat beli (Y) produk smartphone Oppo di Kota Palu. Berdasarkan hasil tersebut dapat disimpulkan bahwa hipotesis pertama terbukti $\left(\mathrm{H}_{0}\right.$ ditolak dan $\mathrm{H}_{\mathrm{a}}$ diterima).

b. Berdasarkan Tabel 3 hasil pengujian dengan SPSS diperoleh angka signifikansi sebesar 0,000. Angka $0,000<0,05$ oleh karena itu, hipotesis diterima. Hal ini berarti variabel $\mathrm{X}_{1}$ (kualitas produk) berpengaruh signifikan terhadap variabel Y (niat beli) produk smartphone merek Oppo di Kota Palu.

c. Berdasarkan Tabel 3 hasil pengujian dengan SPSS diperoleh angka signifikansi sebesar 0,000. Angka $0,000<0,05$ oleh karena itu, hipotesis diterima. Hal ini berarti variabel $\mathrm{X}_{2}$ (fitur produk) berpengaruh signifikan terhadap variabel Y (niat beli) produk smartphone merek Oppo di Kota Palu.

d. Berdasarkan Tabel 3 hasil pengujian dengan SPSS diperoleh angka signifikansi sebesar 0,000. Angka $0,000<0,05$ oleh karena itu, hipotesis diterima. Hal ini berarti variabel $\mathrm{X}_{3}$ (desain produk) berpengaruh signifikan terhadap variabel Y (niat beli) produk smartphone merek Oppo di Kota Palu.

e. Berdasarkan Tabel 3 hasil pengujian dengan SPSS diperoleh angka signifikansi sebesar 0,000. Angka $0,000<0,05$ oleh karena itu, hipotesis diterima. Hal ini berarti variabel $\mathrm{X}_{4}$ (merek produk) berpengaruh signifikan terhadap variabel Y (niat beli) produk smartphone merek Oppo di Kota Palu. 


\section{Pengujian Hipotesis}

Untuk mengetahui pengaruh signifikan secara simultan maupun secara parsial dari variabel independen yakni kualitas produk $\left(\mathrm{X}_{1}\right)$, fitur produk $\left(\mathrm{X}_{2}\right)$, desain produk $\left(\mathrm{X}_{3}\right)$ dan merek produk $\left(\mathrm{X}_{4}\right)$ terhadap variabel dependen yakni niat beli (Y), maka digunaka uji $\mathrm{F}$ dan uji t. Penjelasan lebih lengkapnya akan dijelaskan dibawah.

\section{Uji F (Pengujian Hipotesis Secara Simultan)}

Uji $F$ bertujuan untuk mengetahui apakah variabel independen yakni kualitas produk $\left(\mathrm{X}_{1}\right)$, fitur produk $\left(\mathrm{X}_{2}\right)$, desain produk $\left(\mathrm{X}_{3}\right)$ dan merek produk $\left(\mathrm{X}_{4}\right)$ yang diteliti memiliki pengaruh secara simultan terhadap variabel dependen yakni niat beli (Y) produk smartphone Oppo di Kota Palu.

Berdasarkan Tabel 5.6 terlihat hasil perhitungan diperoleh nilai signifikansi $F=0,000<0,05$. Kesimpulannya adalah bahwa variabel independen yakni kualitas produk $\left(\mathrm{X}_{1}\right)$, fitur produk $\left(\mathrm{X}_{2}\right)$, desain produk $\left(\mathrm{X}_{3}\right)$, dan merek produk $\left(\mathrm{X}_{4}\right)$ secara serempak berpengaruh signifikan terhadap variabel dependen yakni niat beli (Y) produk smartphone Oppo di Kota Palu. Berdasarkan hasil tersebut dapat disimpulkan bahwa hipotesis pertama terbukti ( $\mathrm{H}_{0}$ ditolak dan $\mathrm{H}_{\mathrm{a}}$ diterima).

\section{Uji t (Pengujian Hipotesis Secara Parsial)}

Uji t digunakan untuk mengetahui apakah variabel independen yakni kualitas produk $\left(\mathrm{X}_{1}\right)$, fitur produk $\left(\mathrm{X}_{2}\right)$, desain produk $\left(\mathrm{X}_{3}\right)$ dan merek produk $\left(\mathrm{X}_{4}\right)$ yang diteliti memiliki pengaruh secara parsial terhadap variabel dependen yakni niat beli (Y) produk smartphone Oppo di Kota Palu.

\section{Pembahasan}

1. Pengaruh Dimensi Kualitas Produk dalam Mendorong Niat Beli Produk Smartphone Oppo di Kota Palu

Hasil penelitian menunjukkan bahwa kualitas produk berpengaruh signifikan terhadap niat beli. Kualitas produk yang terdiri atas indikator memiliki baterai tahan lama, memiliki resolusi layar yang tinggi, memiliki sparepart yang mudah didapatkan/dibeli dan kapasitas memori yang besar dapat mendorong niat beli produk smartphone di Kota Palu. Hal ini dikarenakan produk smartphone merek Oppo merupakan produk yang sudah akrab bagi masyarakat melalui iklan-iklan yang tersebar dengan kualitas produk yang ditawarkan tidak kalah saing. Baterai yang tahan lama menjadi indikator yang paling berpengaruh terhadap niat beli produk Smartphone merek Oppo. Hal ini dibuktikan dengan jawaban responden pada Tabel 5.8 yaitu indikator baterai yang tahan lama menjadi indicator dengan nilai mean tertinggi. Penelitian ini didukung oleh pernyataan Tjiptono (2008:24), yang mengatakan bahwa kualitas mencerminkan semua dimensi penawaran produk yang menghasilkan manfaat (benefit) bagi pelanggan. Penelitian ini memiliki hasil yang sama dengan penelitian sebelumnya yang dilakukan oleh Satya dan Giantari (2014) yang menyatakan bahwa kualitas produk berpengaruh secara serempak maupun parsial terhadap niat beli.

2. Pengaruh Dimensi Fitur Produk dalam Mendorong Niat Beli Produk Smartphone Oppo di Kota Palu

Hasil penelitian menunjukkan bahwa fitur produk berpengaruh signifikan terhadap niat beli. Smartphone Oppo memiliki ketajaman gambar yang tinggi sehingga hal ini yang menjadi salah satu alasan yang dapat mendorong niat beli produk smartphone merek Oppo di Kota Palu. Soal kualitas gambar, hasil Oppo tergolong baik, dengan kecerahan warna dan ketajaman yang juga baik, pada kondisi pencahayaan cukup. Tidak hanya kamera depan, smartphone merek Oppo juga mengunggulkan kamera belakang yang turut didukung oleh teknologi Artificial Intelligence (AI). Kehadiran teknologi ini memungkinkan kamera menyuguhkan hasil foto dengan sentuhan fitur beautify yang lebih alami. Selain mendeteksi wajah untuk fitur beautify, teknologi AI pada kamera belakang Oppo juga mampu mendeteksi obyek foto sebagai makanan, orang, pemandangan berupa pantai, langit dan lainnya, kemudian melakukan penyesuaian pada tingkat kecerahan, kontras warna, dan lainnya untuk menampilkan foto yang baik dengan tampilan natural.Seperti yang dikatakan oleh (Sungkar dan Budiatmo, 2016) dalam jurnalnya, bahwa sebuah model awal tanpa tambahan yang menyertai produk tersebut menjadi titik awalnya. Perusahaan yang dapat 
menciptakan model dari tingkat lebih tinggi dengan menambahkan berbagai fitur. Fitur adalah alat persaingan untuk membedakan produk perusahaan terhadap produk sejenis yang menjadi pesaingnya. Menjadi produsen awal yang mengenalkan fitur baru yang dibutuhkan dan dianggap bernilai menjadi salah satu cara yang efektif untuk bersaing.

3. Pengaruh Dimensi Desain Produk dalam Mendorong Niat Beli Produk Smartphone Oppo di Kota Palu

Hasil penelitian menunjukkan dimensi desain produk berpengaruh signifikan terhadap niat beli. Desain produk yang terdiri atas banyak pilihan warna, model yang menarik dan memiliki bentuk yang nyaman untuk digenggam dapat mendorong niat beli produk smartphone Oppo di Kota Palu. Hasil observasi dilapangan, Elegan menjadi kesan yang kami dapati saat pertama kali melihat Oppo, berkat balutan bahan mengkilat yang mendominasi bodi, terutama dibagian belakang. Menggunakan bahan plastik dan bukan metal seperti produk sebelumnya, Oppo mampu menghadirkan kesan ringan saat smartphone digenggam dengan satu tangan. Hasil penelitian ini sejalan dengan penelitian Fimaulida (2010) yang menyimpulkan bahwa desain berpengaruh signifikan dan positif terhadap niat pembelian dan keputusan pembelian. Desain yang baik dan inovatif akan menjadi nilai tambah bagi suatu produk.

4. Pengaruh Dimensi Merek Produk dalam Mendorong Niat Beli Produk Smartphone Oppo di Kota Palu

Hasil penelitian menunjukkan dimensi merek produk berpengaruh signifikan terhadap niat beli. Merek produk yang terdiri atas merek mudah diingat, merek terkenal, nama/simbol berbeda dengan lainnya dan produk mudah didapatkan dapat mendorong niat beli produk smartphone Oppo di Kota Palu. Hal yang menjadi salah satu faktor yang mempengaruhi niat beli yaitu karena smartphone merek Oppo memiliki merek yang mudah diingat. Merek merupakan sebuah nama, istilah, tanda, lambang, desain, atau kombinasi semua ini, yang menunjukan identitas pembuat atau penjual produk. Sama halnya dengan merek smartphone Oppo merupakan merek yang bersaing dengan merek smartphone lainnya. Menurut laporan IDC, OPPO menduduki peringkat kedua merek smartphone di Indonesia pada tahun 2017, dan merupakan merek smartphone nomor satu di China pada tahun 2016. Penelitian ini memiliki hasil yang sama dengan penelitian sebelumnya yang dilakukan oleh Manorek et al. (2016) yang menyatakan bahwa merek berpengaruh signifikan terhadap niat beli.

\section{KESIMPULAN DAN SARAN}

\section{Kesimpulan}

1. Variabel atribut produk yang terdiri atas kualitas, fitur, desain, dan merek secara simultan berpengaruh signifikan terhadap niat pembelian produk smartphone merek Oppo di Kota Palu dengn jumlah responden 50 orang diperoleh angka signifikansi sebesar 0,00 atau $<0,05$, maka hipotesis pertama diterima.

2. Variabel kualitas produk secara parsial berpengaruh signifikan terhadap niat pembelian produk smartphone merek Oppo di Kota Palu dengn jumlah responden 50 orang diperoleh angka signifikansi sebesar 0,00 atau $<0,05$, maka hipotesis kedua diterima.

3. Variabel fitur produk secara parsial berpengaruh signifikan terhadap niat pembelian produk smartphone merek Oppo di Kota Palu dengn jumlah responden 50 orang diperoleh angka signifikansi sebesar 0,00 atau < 0,05, maka hipotesis ketiga diterima.

4. Variabel desain produk secara parsial berpengaruh signifikan terhadap niat pembelian produk smartphone merek Oppo di Kota Palu dengn jumlah responden 50 orang diperoleh angka signifikansi sebesar 0,00 atau $<0,05$, maka hipotesis keempat diterima. 
5. Variabel merek produk secara parsial berpengaruh signifikan terhadap niat pembelian produk smartphone merek Oppo di Kota Palu dengn jumlah responden 50 orang diperoleh angka signifikansi sebesar 0,00 atau $<0,05$, maka hipotesis kelima diterima.

\section{Saran}

Bagi Perusahaan

1. Hasil tanggapan responden pada variabel kualitas produk mengenai indikator kualitas layar merupakan indikator dengan nilai rata-rata terendah. Oleh karena itu, disarankan kepada perusahaan Oppo untuk lebih meningkatkan kualitas layar sehingga tidak kalah saing dengan produk smartphone lainnya.

2. Hasil tanggapan responden pada variabel fitur mengenai indikator banyaknya aplikasi yang membantu kesibukan sehari-hari merupakan indikator dengan nilai rata-rata terendah. Oleh karena itu, disarankan kepada perusahaan Oppo untuk lebih meningkatkan aplikasi yang dapat membantu para penggunasmartphone Oppo yang sesuai dengan kebutuhan.

3. Hasil tanggapan responden pada variabel desain produk mengenai indikator banyaknya pilihan warnamerupakan indikator dengan nilai rata-rata terendah. Oleh karena itu, pihak perusahaan harus memperbanyak pilihan warna dan harus bisa menciptakan warna baru yang lebih elegan dan berbeda dari para pesaing-pesaing lainnya.

4. Hasil tanggapan responden pada variabel merek mengenai indikator salah satu merek smartphone yang mendunia merupakan indikator dengan nilai rata-rata terendah. Oleh karena itu, disarankan pada perusahaan Oppo untuk meningkatkan promosi baik dari media massa atau media cetak di dalam dan luar negeri.

5. Bagi Peneliti Selanjutnya

Bagi peneliti selanjutnya yang ingin meneliti atau melanjutkan penelitian ini, disarankan untuk meneruskan atau mengembangkan penelitian ini dengan mencari faktor lain yang dapat mempengaruhi niat pembelian seperti faktor citra perusahaan, harga, dan kualitas produk.

\section{REFERENSI}

Abdullah, T., dan Tantri, F. (2014). Manajemen Pemasaran. Jakarta: PT Raja Grafindo Persada.

Assael, H. (1998). Consumer Behavior \& Marketing Action. South Western Pub.

Ghozali, I. (2005). Aplikasi Analisis Multivariate Dengan Program SPSS (Ketiga). Semarang: Badan Penerbit Universitas Diponegoro.

Kotler, P. (2008). Principles of Marketing (12th ed.). England: Pearson Education.

Kotler, P., dan Armstrong, G. (2012). Prinsip-prinsip Pemasaran (Ketigabelas). Jakarta: Erlangga.

Kotler, P., dan Armstrong, G. (2013). Principles of Marketing (Fourteenth). England: Pearson Education.

Kuncoro, M. (2009). Metode Riset Untuk Bisnis \& Ekonomi (Ketiga). Jakarta: Erlangga.

Malau, H. (2017). Manajemen Pemasaran. Bandung: Alfabeta CV.

Manorek, S. L., Pangemanan, S. S., \& Rumokoy, F. (2016). The Influence of Brand Image, Advertising, Perceived Price toward Consumer Purchase Intention at Samsung Smartphone. Jurnal EMBA: Jurnal Riset Ekonomi, Manajemen, Bisnis Dan Akuntansi, 3(4), 593-601.

Priyatno, D. (2008). Mandiri Belajar SPSS. Yogyakarta: Mediakom.

Santoso, S. (2014). Statistik Multivariat (Revisi). Jakarta: PT.Elex Media Komputindo. 
Satya, M. M., dan Giantari, K. (2014). Pengaruh Brand Image, Celebrity Endorser, Kualitas Produk, Dan Kewajaran Harga Terhadap Niat Membeli Sepeda Motor Matic Merek Honda Di Kota Denpasar. E-Journal Manajemen Universitas Udayana3, 10, 2869-2886.

Sugiyono. (2014). Metode Penelitian Kuantitatif, Kualitatif, dan R\&D. Bandung: Alfabeta.

Sugiyono. (2015). Metode Penelitian Kuantitatif, Kualitatif, dan Kombinasi (Mixed Methods). Bandung: Alfabeta CV.

Sungkar, N. F., dan Budiatmo, A. (2016). Pengaruh Iklan, Atribut Produk, dan Harga Terhadap Keputusan Pembelian (Studi pada Pembeli dan Pengguna Oppo Smartphonedi Kota Semarang). Jurnal Administrasi Bisnis, 5(1), 35-45.

Sunyoto, D. (2014). Konsep Dasar Riset Pemasaran dan Perilaku Konsumen (Kedua). Yogyakarta: CAPS (Center for Academic Publishing Service).

Tjiptono, F. (2008). Strategi Pemasaran. Yogyakarta: CV Andi Offset. 